\title{
Adverse consequences of economic policy in combating global climate change in the Czech Republic
}

\author{
ZDENĚK PIKHART $^{1 *}$ (E), ŠÁRKA PIKHARTOVÁ ${ }^{2}$ and \\ PAVEL PROCHÁZKA ${ }^{1}$
}

\footnotetext{
${ }^{1}$ Faculty of Finance and Accounting, University of Economics, Prague, Czech Republic

${ }^{2}$ Faculty of Economics, University of Economics, Prague, Czech Republic
}

Received: July 17, 2020 • Revised manuscript received: November 20, 2020 • Accepted: January 15, 2021

Published online: February 12, 2021

(c) 2021 The Author(s)

\begin{abstract}
The main aim of the article is to identify unintended consequences of economic policies to combat climate change, in the short and long run, using the example of the Czech economy. The short term impacts are assessed by world input-output analysis in order to capture direct and indirect channels affecting the Czech automotive industry. Optimistic, realistic and pessimistic scenarios of decrease in demand for cars due to the imposition of environmental taxes in the European Union and the rest of the world are presented. The results show adverse impacts on Czech gross domestic product from 1.6 to 4.9 percentage points. The economy is expected to change its structure and reallocate factors of production to an alternative use, but there is a risk of suboptimal allocation, which might reveal losses from less efficient allocation of labor and capital. Therefore, the analysis of the relationship between economic welfare and the quality of the environment is conducted. Data on the Czech economy confirm the hypothesis of an environmental Kuznets curve and point to unintended consequences of overly ambitious policies to mitigate global climate change. If economic welfare excessively declines, there would be a significant risk of undermining people's will to invest into environmental protection.
\end{abstract}

\section{KEYWORDS}

Kuznets curve, global climate change, input-output analysis, environmental policy

JEL CODES

D57, Q51, Q54

*Corresponding author. E-mail: zdenek.pikhart@mfcr.cz 


\section{INTRODUCTION}

Global climate change and the consequences of global warming are a much-discussed and also controversial topic. Environmentalists and activists point to the growing amount of greenhouse gases in the atmosphere and mention the catastrophic effects of climate change on mankind and the planet's ecosystem. From the causes of global warming, through the evaluation of the consequences of climate change, to the solution of the problem, contradictory attitudes can be found in the literature. The reason for the complexity of this problem is the uncertainty of forecasts decades ahead.

The European Union (EU) is the world leader in reducing the amount of greenhouse gases produced by human activity and thereby preventing, or at least slowing down, global warming. Based on EU legislation (European Commission, 2019), individual member states are implementing economic policy measures to reduce greenhouse gas emissions, and thus mitigate climate change with its negative effects. However, this could have undesirable consequences for economies, as the individual sectors of the economy are interconnected.

The negative effects of global warming are emphasized in the literature and in the media. Global climate change is associated with poor environmental quality. Researchers believe that the underlying problems are caused by man-made global warming (Meadows et al. 1972; Anderson et al. 2001; Gore 2006; Greenwalt 2016). They cite high concentrations of greenhouse gases in the atmosphere as the cause of global warming. The IPPC Special Report on Global Warming of $1.5^{\circ} \mathrm{C}$ (IPCC 2018) mentions that global temperature rise by $1.5^{\circ} \mathrm{C}$ will significantly increase the risks of world poverty and have negative effects on ecosystems. The member states of the EU, which under the 2016 Paris Agreement ${ }^{1}$ (United Nations, 2015) committed to reduce greenhouse gas emissions by at least $40 \%$ by 2030 compared to 1990 , try to reverse this trend.

The main source of greenhouse gas emissions is the ongoing population explosion (Ehrlich, 1968). This requires higher agricultural production, which decreases wooded areas naturally reducing greenhouse gases in atmosphere. The most frequently reported consequences of climate change are extreme weather events and unstable climate conditions, such as excessively high or low temperatures, windstorms, drought fires, earthquakes, volcanic activity or floods due to sudden torrential rains, melting of glaciers and rising sea levels. The people of the coastal areas will be forced to move to other parts of the world that are safer. The intensity of the impacts will vary across countries (Leary et al. 2008).

All of the above scenarios and hypotheses are approached according to the precautionary principle and the economic policy recommendations for delaying climate change have been implemented hastily, without a priori economic cost-benefit analysis. Certain impact assessments arise, but rather ex post (e.g. European Commission 2020b). However, it is necessary to build up appropriate measures to tackle global warming on a priori cost-benefit analysis. It should be considered whether the introduction of measures will in fact have the desired effect or whether it would rather slow down economic development excessively. At the same time, it is the degree of economic welfare that enhances the humanity's ability to adapt.

The possible positive effects of global warming are neglected compared to the negative effects. It should be noted that a large part of the world can benefit from a higher average global

${ }^{1}$ Paris Agreement under the United Nations Framework Convention on Climate Change signed in 2016. 
temperature. Some northern areas not previously used for agriculture may find agricultural use due to the changed climate. Increasing concentrations of carbon dioxide are beneficial for agriculture, as carbon dioxide acts as a fertilizer that increases the profitability of agricultural production (Darwin - Kennedy 2000; Deryng et al. 2016). Thanks to higher temperatures, energy savings can be realized and the increasing intensity of sunlight together with a windier climate can increase the use of alternative energy sources. Regarding the impact on human health, experts mention as a positive the lower mortality caused by higher temperatures (Loužek, 2007). Paradoxically, climate change can contribute to more efficient international trade, as the melting of ice caps is expected to open up the North Sea route between continents and thus speed up trade.

This is just an outline of the possible positives that a warmer climate can bring. In fact, thanks to human adaptability, whole countries, not just certain areas, can benefit from mild global warming.

A crucial role in the extent to which the changed climate will affect the overall economic situation is the future adaptability of society, which in principle cannot be estimated. Society's adaptability to rising temperatures will also be dependent on the time horizon of rising average temperatures. The slower pace of global warming, the more efficient allocation of scare sources to adaptation will be.

Model scenarios of global temperature growth from 1990 till 2060 are in range of $0.9-3.0{ }^{\circ} \mathrm{C}$ (Hope 2006; Rehdanz - Maddison 2005). The average width of the interval is 2.5 percentage points.

Certain analyses (Stern 2006) predict a decline in gross domestic product (GDP) mainly due to repair and adaptation costs but others (Tol 2014) estimate a positive effect on GDP in most parts of the world given a slight increase in temperatures. The impacts of climate change differ across sectors and economies. For instance, Mendelsohn (2009) reports that a global increase in temperature by $2.5{ }^{\circ} \mathrm{C}$ will cause a decrease in GDP of developing countries by $0.17 \%$ and in developed world an increase by $0.03 \%$, which are both globally quite negligible effects. Similarly, conclusions of international organizations are ambiguous. The International Monetary Fund (2019) points to different relationships between temperature and labor productivity across sectors. In regions with temperatures below average, a $1{ }^{\circ} \mathrm{C}$ increase in temperature would raise labor productivity in the service sector. In the regions with average annual temperature above average, on the contrary, rising temperature might lead to lower productivity in the agriculture and industry sector.

The future cannot be perceived form today's perspective. Technology and society have made a great progress, which was hardly imaginable decades ago. Cyclical fluctuations and various unforeseen events will still be present in the future, but it can be assumed that free trade societies will become richer, existing technologies will continue to improve and new technologies will be developed. Therefore, it is absolutely impossible to present catastrophic scenarios of the development of society and nature without knowledge of the future state and knowledge. Most of the current studies apply the so-called precautionary principle (Stern 2006), which is in conflict with opportunity cost principle. As a result, the discount factors for future costs of global climate change have been underestimated, not reflecting real risk premium, which is widely criticized (Nordhaus 2007; Nordhaus and Moffat, 2017).

The main aim of this article is to identify unintended consequences of economic policies to combat climate change, both immediately after the introduction of these policies and in the long 
run, on the example of the industrial Czech economy. The second section focuses on short term impacts of imposing environmental taxes on the automotive industry by using the world inputoutput tables.

Due to the diversity of methods, it is difficult to compare the results of the models which is also the reason why their estimates often differ. Researchers also try to understand the relationship between economic growth and global climate change from another perspective, i.e. the extent to which growing prosperity is the cause of climate change through greenhouse gas emissions into the atmosphere. Richer societies tend to invest more into the protection of nature. This is not a critique of environmental measures as such, because even inaction takes substantial costs. But the study points to the risk of unveiling possible inefficiency of measures based on dogmatic precautionary principle, which might lead to excessive impoverishment reflected in lower propensity to protect our environment. This context will be discussed in more detail in the third section.

\section{SHORT TERM IMPACTS}

Implementing measures to combat global climate change will not be possible without short term economic fluctuations. Greenhouse gas reduction is most often achieved through standards and environmental taxes. In the context of the Czech economy, such measures will primarily affect the automotive industry, which represents approximately $11 \%$ of the Czech Republic's GDP and its share ${ }^{2}$ in total exports of goods in 2019 reached 29.2\% (Czech Statistical Office 2020a). Tightening of EURO standards for cars and the introduction of charges for above-limit greenhouse gas emissions will make the purchase price of petrol and diesel cars less affordable and as a result sales, production and employment in the manufacturing sector will be reduced. The factors of production, labor and capital, will shift to alternative uses in the medium to long term, but in the short term there may be a significant shortfall in Czech economic activity.

Supply chains have been tightly interconnected for many years. Thus, the relatively sharp tightening of environmental measures affects the automotive industry heavily. The development of automobile models, engines and components has been a process of many years. Accumulated know-how in the production of petrol and diesel engines must be abruptly abandoned by car manufacturers and alternatives must be urgently sought. New regulation will lead to massive electrification of cars, which will only shift the problem of emissions from manufacturing to the energy industry. Both sectors would need much more time to develop truly emission-free alternatives, but this is not provided by the regulator in the form of the EU.

Due to the rapid rise in prices of conventional vehicle drives and high prices of electrified alternatives, a reduction in demand for cars by households and companies can be expected. By nature, this is a structural change, not a fluctuation of the economic cycle. It will take several quarters or years for the released resources to be fully absorbed by other sectors.

With its new, with EURO 6d standards (Regulation EU 2019/631) that have been introduced in 2020 , the EU is pushing for the price of conventional vehicles to increase, thereby encouraging customers and producers to prefer hybrids and electric cars. The limit of average $\mathrm{CO}_{2} \mathrm{car}$ emissions free of fines has been set at $95 \mathrm{~g} \mathrm{CO}_{2} / \mathrm{km}$ since 2020, while the average $\mathrm{CO}_{2}$ emissions

${ }^{2}$ Commodity groups "Motor vehicles, trailers and semi-trailers" and "Other transport equipment". 
of new cars in the EU in 2019 were $121.8 \mathrm{~g} / \mathrm{km}$ (JATO Dynamics 2020). For 2030, the European Commission's target is to reduce average $\mathrm{CO}_{2}$ emissions below $60 \mathrm{~g} / \mathrm{km}$ (ICCT 2016; Regulation EU 2019/631). ${ }^{3}$

The Report of International Energy Agency (IEA 2017) outlines the ways for improving the fuel economy of conventional gasoline and diesel road vehicles. The Report shows market-ready technologies that could reduce the specific fuel consumption of new vehicles. But these costly improvements will cause a noticeable rise in car prices.

In this part of the article, several probable scenarios of the nearest development are presented. Fines for exceeding the emission limits or more complicated technologies will make cars more expensive. With respect to several studies on demand elasticities for motor vehicles (see Table 1), price elasticity of demand for motor vehicles is set as a simple average of other authors' estimations of elasticities from the sample. Based on the average price elasticity, a $1 \%$ increase in price will cause a $1.99 \%$ reduction in quantity demanded. ${ }^{4}$ Motor vehicles are a longterm (durable) consumer good with elastic demand, higher value of the price elasticity for durable goods is also consistent with economic theory. Consumption of durable goods can be significantly reduced, older products can be utilized for a longer period of time, or they are assessed as a luxury good. In case of companies' investments into motor vehicles, the demand can be expected to be more elastic due to availability of substitutes.

In following analysis, three scenarios are presented to meet the EU's emission targets optimistic, realistic and pessimistic. From methodological point of view, the quantification of demand shocks is realized through world symmetric input-output tables published by the OECD (2018). The advantage of the input-output analysis approach is that it captures the indirect

Table 1. Price elasticity for motor vehicles (selected studies)

\begin{tabular}{|l|c|c|}
\hline Authors & Region of survey & Elasticity \\
\hline Anderson et al. (1997) & USA & -1.20 \\
\hline Train and Winston (2007) & USA & -1.65 \\
\hline Copeland (2009) & USA & -1.67 \\
\hline Vance and Mehlin (2009) & Germany & -1.49 \\
\hline Janský (2014) & Czech Republic & -2.18 \\
\hline Moraga-González et al. (2015) & Netherlands & -3.77 \\
\hline Average elasticity of the sample & & -1.99 \\
\hline
\end{tabular}

Source: authors.

\footnotetext{
${ }^{3}$ Even the year 2030 may not be final. According to Randall (2020) and NewsABC (2020), the European Commission will propose the introduction of a new Euro 7 emission standard from 2025 instead of previously declared 2030 in Regulation (EU) 2019/631.

${ }^{4}$ Among the authors' estimations, survey for the Czech case is also mentioned. Despite that fact we apply a single price elasticity to the whole sample, the estimation of elasticity based on more relevant resources is more appropriate than using one case to evaluate changes on Czech output.
} 
effects of responses of primary shocks through subcontracting international supply chains (in case of Czech economy). A disadvantage of this approach is its significant data input intensity and resulting publication delays (approximately three years).

Various input-output (I-O) analysis potentials are explained in detail in the literature (Isard - Langford 1971; Miller - Blair 2009). A characteristic attribute of symmetric inputoutput models, in contrast to the neoclassical production function or the Leontief production function, which is based on the assumption of constant returns to scale and the condition of constant output (fixed amount of each input is required to produce one unit of output), is that they capture sales (transactions) from the selling industry to the purchasing industry and components of final demand (household's final consumption expenditure, general government final consumption, gross fixed capital formation etc.). I-O tables are published divided into domestic use, import use and total use, which is convenient for estimating the import intensity of final demand components. For the purposes of our analysis, we focus on total use.

Cross-sectoral chains within the I-O tables can be characterized with Eq. (1), where $x_{i}^{\text {tot }}$ denotes the total output (production) of a particular industry, which is sold to the same industry and the other industries $z_{i n}^{\text {tot }}$, and to final demand $f_{i}^{\text {tot }}$ within the Czech Republic, the rest of the $\mathrm{EU}$, and the rest of the world:

$$
x_{i}^{\text {tot }}=z_{i 1}^{\text {tot }}+z_{i n}^{\text {tot }}+\ldots+z_{\text {in }}^{\text {tot }}+f_{i}^{\text {tot }}=\sum_{j=1}^{n} z_{i j}^{\text {tot }}+f_{i}^{\text {tot }}
$$

The distribution of each industry's sales of goods and services to the same and other industries and final demand in the Czech Republic and abroad can be summarized in matrix vectors:

$$
\left[\begin{array}{c}
x_{1}^{\text {tot }} \\
\vdots \\
x_{n}^{\text {tot }}
\end{array}\right]=\left[\begin{array}{ccc}
z_{11}^{\text {tot }} & \ldots & z_{1 n}^{\text {toto }} \\
\vdots & \ddots & \vdots \\
z_{n 1}^{\text {tot }} & \ldots & z_{n n}^{\text {tot }}
\end{array}\right]+\left[\begin{array}{c}
f_{1}^{\text {tot }} \\
\vdots \\
f_{n}^{\text {tot }}
\end{array}\right]
$$

Otherwise production matrix $X$ is a sum of interindustry sales matrix $Z^{\text {tot }} X=Z^{\text {tot }}+f$ and final demand matrix:

$$
X=Z^{\text {tot }}+f
$$

These relationships are used to set a matrix of technical coefficients $A$, which represent the ratio of intermediates used in consumption of the industry to their total production of industry. As an illustration, for example, the value of production sold from the agricultural sector to the mining and quarrying sector to the total production of the mining and quarrying sector can be written as follows:

$$
\mathrm{A}=\left[\begin{array}{ccc}
\frac{z_{11}^{\text {tot }}}{x_{1}^{\text {tot }}} & \ldots & \frac{z_{1 n}^{\text {tot }}}{x_{n}^{\text {tot }}} \\
\vdots & \ddots & \vdots \\
\frac{z_{n 1}^{\text {tot }}}{x_{1}^{\text {tot }}} & \ldots & \frac{z_{n n}^{\text {tot }}}{x_{n}^{\text {tot }}}
\end{array}\right]=\left[\begin{array}{ccc}
a_{11}^{\text {tot }} & \ldots & a_{1 n}^{\text {tot }} \\
\vdots & \ddots & \vdots \\
a_{n 1}^{\text {tot }} & \ldots & a_{n n}^{\text {tot }}
\end{array}\right]
$$


$I$ is a square unit matrix with the same number of sectors (rows) as the matrix of technical coefficients $A$ with 1 on the main diagonal and 0 outside of it. Subtract the above matrix of technical coefficients from the unit matrix:

$$
\mathrm{I}=\left[\begin{array}{ccc}
1 & \ldots & 0 \\
\vdots & \ddots & \vdots \\
0 & \ldots & 1
\end{array}\right] \text { then }(\mathrm{I}-\mathrm{A})=\left[\begin{array}{ccc}
\left(1-a_{11}^{t o t}\right) & \ldots & -a_{1 n}^{t o t} \\
\vdots & \ddots & \vdots \\
-a_{n 1}^{t o t} & \ldots & \left(1-a_{n n}^{t o t}\right)
\end{array}\right]
$$

From the relationship between the unit and the inverse matrix we get the Leontief inverse matrix $L$ :

$$
\begin{aligned}
& I=(I-A)(I-A)^{-1} \\
& L=(I-A)^{-1}
\end{aligned}
$$

Multiplying the Leontief inverse matrix (also called the Leontief multiplier) with final demand $f$, we get total output $X$ :

$$
X=(\mathrm{I}-\mathrm{A})^{-1} f=L f
$$

By transferring the given relation into a growth form, we get the change of total output $\Delta X$ as a result of a change in the final demand $\Delta f$ :

$$
\Delta X=L f^{1}-L f^{0}=L \Delta f
$$

This I-O analysis captures the impact of initial changes in final demand in the domestic economy and abroad on the production of the domestic economy (in our case, on the Czech economy), according to the actual interconnectedness of the sectors with each other within the world economy. Finally, changes in intermediate consumption $\Delta Z$ within industry supply chains must also be deducted from changes in production to catch changes in gross value added $\triangle G V A$ :

$$
\Delta G V A=\Delta X-\Delta Z
$$

In order to assess the impacts of decline in demand for vehicles, world symmetric I-O tables published by the OECD (2018) are used, which include economic relations between the 69 countries, divided into 36 sectors.

For the sake of simplification, countries are divided into three groups: the Czech Republic, rest of the EU (Czech Republic's main trading partner and the area with common regulation framework) and the rest of the world. Given the role of the car industry in the Czech economy, impacts of price increases and drops in demand for motor vehicles are simulated in three different scenarios. These scenarios were set as various bands of possible price increases in respect of average $\mathrm{CO}_{2}$ emissions and financial penalties for exceeding emission limits. Based on JATO Dynamics analysis (2020), in 2019 average $\mathrm{CO}_{2}$ emissions in EU reached $121.8 \mathrm{~g}$ $\mathrm{CO}_{2} / \mathrm{km}$ (in Germany $129.9 \mathrm{~g} \mathrm{CO}_{2} / \mathrm{km}$, in the Czech Republic $126.9 \mathrm{~g} \mathrm{CO}_{2} / \mathrm{km}$ ). Taking the financial penalty, 95 EUR per each gram above the limit of $95 \mathrm{~g} \mathrm{CO}_{2} / \mathrm{km}$ and the knowledge of the average retail price of vehicles in 2018 (International Council on Clean Transportation 2019; Statista 2019), reimbursement of costs for exceeding the prescribed emission limit could 
lead to an increase motor vehicle prices by $11.0 \%$ in the EU overall, $11.8 \%$ in Germany, $7.1 \%$ in France, $16.1 \%$ in Central and Eastern Europe, and $16.3 \%$ in the Czech Republic. ${ }^{5}$

Given the different impacts across EU member states, our study sets several bands of potential increases in prices. The first scenario (optimistic) is taking into account the decline in final demand for passenger cars, trailers and semi-trailers in the Czech Republic (CZ) and the rest of the EU due to price increases by $10 \%$ which is the lower band of expected price growth. Considering the fact that emission limits are compulsory only in EU countries, we abstract from any growth of prices outside the EU. The second scenario (realistic) is based on the assumption of a shortfall in demand for motor vehicles as a result of price growth by $20 \%$ in the Czech Republic and the EU (the upper band of cost calculation in several EU countries is taken into account) and $5 \%$ in the rest of the world. ${ }^{6}$ The third scenario (pessimistic) expects significant growth of prices by $30 \%$ in the Czech Republic and the EU and $10 \%$ in the rest of the world. This scenario is more theoretical, it is set on the assumption of a faster implementation of EURO 7 emission standards after 2025, pressures on potential faster low carbon mobility, additional costs of car manufacturers to finance $R \& D$ in this segment and their need to make some financial reserves for other financial penalties. Price increase in this scenario is set arbitrarily. All scenarios of price increases and associated reactions of demand for motor vehicles are summarized in Table 2.

In case of transition to zero carbon mobility, the European Commission (2020a) pointed out that a neutral carbon policy in combination with the European Green New Deal will stimulate jobs due to new possibilities brought by the latest EU strategy. But, in the short term, production capacities broadly oriented to traditional car drives are expected to drop due to a quick imposition of environmental financial penalties. Current prices of electric and hybrid cars significantly exceed prices of traditional vehicles even after the financial sanctions have been included. A significant impact on employment in the short term can also be expected because

Table 2. Summary of all scenarios and their assumptions

\begin{tabular}{|l|c|c|c|c|}
\hline \multirow{2}{*}{} & \multicolumn{3}{|c|}{ Change in motor vehicles price in... } & \multicolumn{2}{c|}{$\begin{array}{c}\text { Response of demand for motor vehicles } \\
\text { in. . }\end{array}$} \\
\cline { 2 - 5 } & CZ and EU & Rest of the World & CZ and EU & Rest of the World \\
\hline Scenario 1 & $10 \%$ & $0 \%$ & $-19.90 \%$ & $0.00 \%$ \\
\hline Scenario 2 & $20 \%$ & $5 \%$ & $-39.80 \%$ & $-9.95 \%$ \\
\hline Scenario 3 & $30 \%$ & $10 \%$ & $-59.70 \%$ & $-19.90 \%$ \\
\hline
\end{tabular}

Source: authors.

\footnotetext{
${ }^{5}$ The situation is also different across the segment. For example, average price per mainstream (compact) vehicles would rise by $17.4 \%$ in Germany and $17.6 \%$ in the Czech Republic.

${ }^{6}$ Lower impacts on the demand for cars in the rest of the world are the result of absence of emission standards outside the EU. The study considers moderate growth of motor vehicle prices as part of the effort to get funds for the payment of emission fees, partly because some countries are also members of European Economic Area which implies same regulation framework as EU members.
} 
electric vehicles will not require many of the components that are labor-intensive to produce (e.g. transmissions). Ultimately, these changes will also affect traditional supply-and-demand relations and energy prices. ${ }^{7}$ In the medium term, there will be a broader reallocation of resources into low carbon vehicles' production. The long term impact on GDP will depend on whether the decline in quantity outweighs the increase in quality (more ecofriendly goods). But cars will likely become a less affordable and more luxurious good in the near future which will have unforeseen impacts on ways of living (see Section 3).

The results presented in Tables 3-5 show the short term impact of percentage changes in prices of motor vehicles on total production, GDP and its components (domestic demand, export, import), compared to the baseline scenario which represents potential economic growth without supply shocks on motor vehicle's price level. The estimated results represent potential

Table 3. Optimistic scenario: price increase of $10 \%$ in $\mathrm{CZ}$ and the EU; $0 \%$ in the rest of the world

\begin{tabular}{|c|c|c|}
\hline & $\Delta$ million USD & $\Delta \%$ \\
\hline Total production & $-6,971.1$ & -1.61 \\
\hline GDP & $-2,848.4$ & -1.60 \\
\hline \multicolumn{3}{|c|}{ Contributions to GDP growth ( $\Delta$ million USD, $\Delta \mathrm{pp}$ ) } \\
\hline Domestic demand & $-1,754.9$ & -0.98 \\
\hline Export & $-4,774.8$ & -2.68 \\
\hline Import & $-3,681.3$ & -2.07 \\
\hline
\end{tabular}

Source: authors.

Table 4. Realistic scenario: price increase of $20 \%$ in $\mathrm{CZ}$ and the EU; $5 \%$ in the rest of the world

\begin{tabular}{|l|c|c|}
\hline & $\Delta$ million USD & $\Delta \%$ \\
\hline Total production & $-15,480.2$ & -3.58 \\
\hline GDP & $-5,853.7$ & -3.28 \\
\hline Contributions to GDP growth $(\Delta$ million USD, $\Delta \mathrm{pp})$ & -1.97 \\
\hline \multicolumn{2}{|c|}{ Domestic demand } & $-3,509.9$ \\
\hline Export & $-9,798.6$ & -5.50 \\
\hline Import & $-7,454.7$ & -4.18 \\
\hline
\end{tabular}

Source: authors.

\footnotetext{
${ }^{7}$ The paper also abstracts from the potential positive impacts of subsidies for the purchase of an electric and hybrid vehicles in some EU countries. Production of electric and hybrid vehicles by Czech car manufacturers is on a marginal level right now. According to the Transport Research Centre (2020), the production of electric and hybrid vehicles in local manufacturing reached only $0.04 \%$ of total car manufacturing.
} 
Table 5. Pessimistic scenario: price increase of $30 \%$ in $\mathrm{CZ}$ and the EU; $10 \%$ in the rest of the world

\begin{tabular}{|l|c|c|}
\hline & $\Delta$ million USD & $\Delta \%$ \\
\hline Total production & $-23,989.4$ & -5.55 \\
\hline GDP & $-8,829.0$ & -4.95 \\
\hline Contributions to GDP growth $(\Delta$ million USD, $\Delta \mathrm{pp})$ \\
\hline Domestic demand & $-5,264.8$ & -2.95 \\
\hline Export & $-14,822.4$ & -8.31 \\
\hline Import & $-11,258.2$ & -6.32 \\
\hline
\end{tabular}

Source: authors.

losses in GDP growth and the growth dynamics of its components in percentage points if any of presented scenarios materialize.

In the first case, the decrease in final demand (in the Czech Republic and the EU) for motor vehicles would result in a one-off reduction in total production by $1.61 \%$. GDP ${ }^{8}$ in the Czech economy as a whole would shrink by $1.60 \%$. The Czech economy would be hit by both domestic and external demand reduction in the EU (especially in Germany, in relation to which the Czech Republic is a major subcontracting exporter).

Based on the second scenario, which includes the decline in demand for motor vehicles in the rest of the world as well, the overall impact of a slowdown in domestic and external demand could reduce production by $3.58 \%$. GDP would be hit by $3.28 \%$. Drop in domestic demand would lead to a negative contribution to GDP by almost two percentage points (1.98 pp). The contraction of exports (5.50 pp), also contributes to the decrease in GDP, but it would be partly compensated by lower imports (by $4.18 \mathrm{pp}$ ).

The pessimistic scenario considers a deeper impact of emission standards on demand for motor vehicles and its components also in the rest of the world. In this simulation, general production of the economy would be down by $5.55 \%$. GDP in the economy as a whole would shrink by $4.95 \%$. Decrease in exports is in this case almost three times higher than the decrease in domestic demand, which proves the foreign-orientated structure of the economy.

At first glance, these impacts show what one struggling (and in the Czech and the European context significant) sector may cause. For a better explanation, it is necessary to set them in the context of macroeconomic development in the Czech Republic. Taking into account the materialization of the first scenario (optimistic) and long term development of Czech GDP (in 2010 and 2019 average real GDP annual growth rate was 2.3\%) as a baseline scenario, the Czech economy would balance on the edge of recession due to a $0.7 \%$ decrease in demand for motor vehicles alone. A possible deterioration in confidence in other sectors of the economy (in the form of a reduction in investment activity by enterprises or household spending) may cause a decline in demand in other economic sectors and lead to yet another economic crisis.

${ }^{8} \mathrm{I}-\mathrm{O}$ analysis primarily captures changes in gross value added. In the calculation we substitute value added with domestic product (we abstract from changes in taxes). This adjustment can help us present impacts of price growth of motor vehicles on components of GDP: domestic demand and net exports. 


\section{UNINTENDED CONSEQUENCES IN THE LONG TERM}

Global economic development has long been seen by many scientists and politicians as a source of the devastation of nature. Due to this pressures on the sustainability of economic growth have been increasing and there is a tendency to artificially suppress economic growth in order to improve the environment and fight against climate change. But causality between economic welfare and environmental quality is somewhat ambiguous and non-linear. This is the reason why policies which dampen economic activity might result in the deterioration of the environment. We outline the relationship between air quality and economic welfare, the so called environmental Kuznets curve (Kuznets 1955), in the case of the Czech Republic.

Up to a certain level of GDP per capita, economic growth really deepens the environmental burden, but only to the turning point from which, on the contrary, environmental pollution decreases with further economic growth. The literature (Grossman - Krueger 1994) reports a turning point value of USD 6,700-8,400 GDP per capita. Above this level of GDP, the quality of the environment improves with the further increase of economic welfare. This relationship and the turning point are shown in Fig. 1.

Based on a comparison of real GDP per capita $(1999=100)$ and the concentration of emissions per capita, we estimate the relationship between economic welfare and air quality in the Czech Republic. From the data of the Czech Statistical Office mapping the period between 1990 and 2019, it is possible to observe how total emissions developed in connection with the level of real GDP per capita. The individual monitored components of total emissions, including solid pollutants, sulfur dioxide, nitrogen oxide and carbon monoxide, had a declining trend with increasing real GDP per capita, as shown in Figs. 2-5. The evolution of total greenhouse gas emissions is shown in Fig. 6.

In the observed period from 1990 to 2017, real GDP per capita shows an increasing trend accompanied by declining emissions. This fact can be explained by the greater interest in the quality of the environment as economic welfare grows. As society gets richer, it cares more about the environment. From the above, it is clear that Czech society has been able to adapt flexibly during the economic transformation period and reduce overall emissions. The state of the environment and air quality are closely linked to the level of investment into air protection. The situation in the Czech Republic has been in line with the decreasing right hand side (post-peek) of the Environmental Kuznets curve.

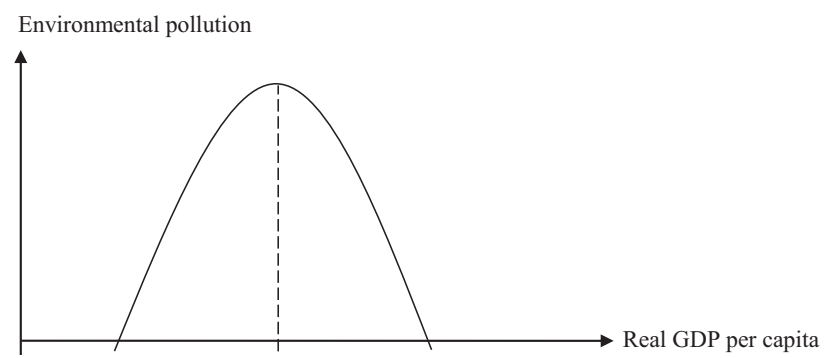

Fig. 1. Environmental Kuznets curve.

Source: authors 


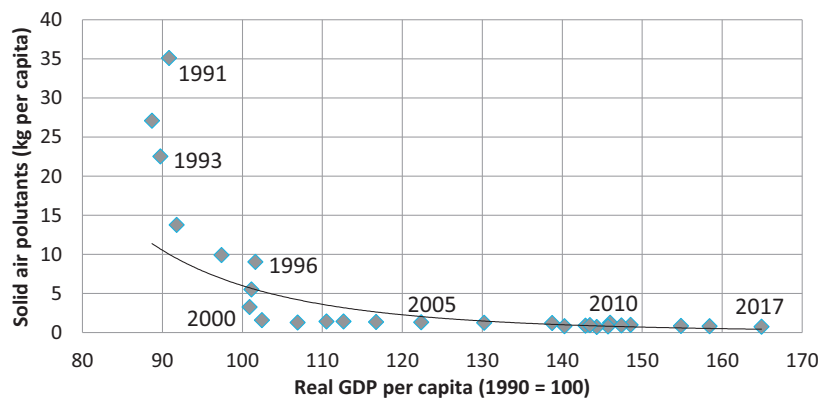

Fig. 2. Emissions of solid air pollutants and real GDP per capita in the Czech Republic. Source: Czech Statistical Office (2020b)

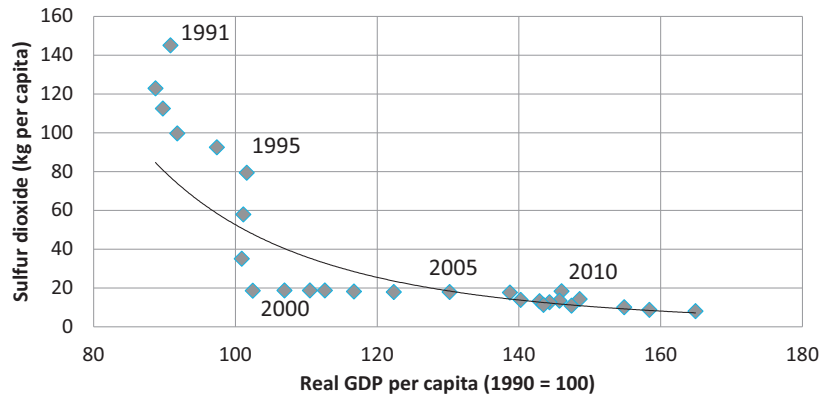

Fig. 3. Emissions of sulfur dioxide and real GDP per capita in the Czech Republic. Source: Czech Statistical Office (2020b)

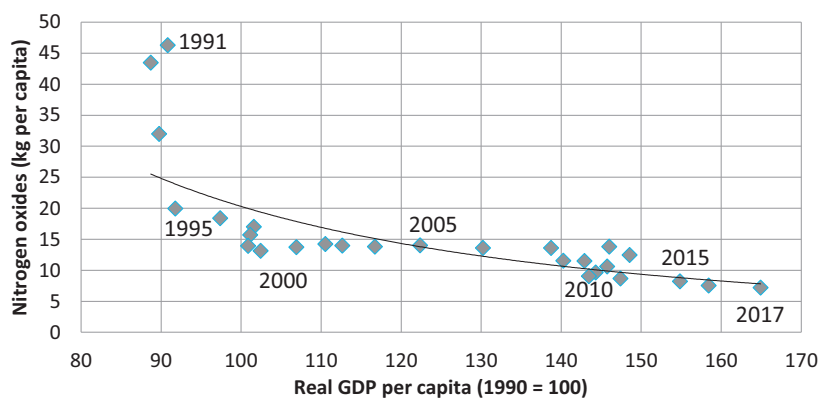

Fig. 4. Emissions of nitrogen oxides and real GDP per capita in the Czech Republic. Source: Czech Statistical Office (2020b)

The development of investments in air protection after 1990 is shown in Fig. 7. This Ushaped relationship is explained by the heritage of high ecological damage accumulated during the communist era, which needed to be sanitized in early 1990s. There has been a steep increase 


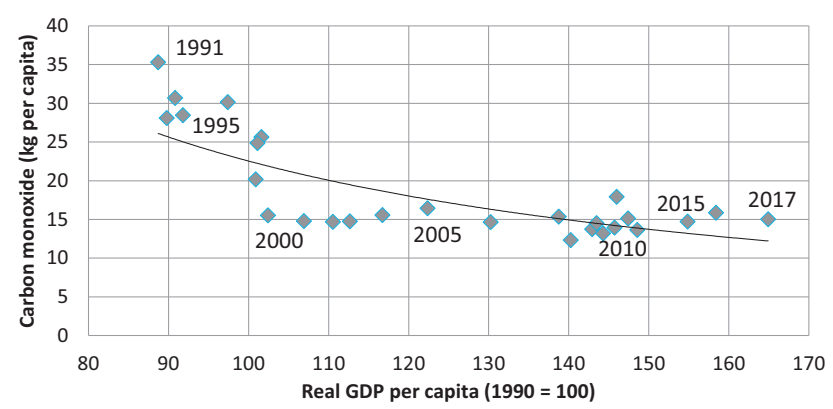

Fig. 5. Emissions of carbon monoxide and real GDP per capita in the Czech Republic.

Source: Czech Statistical Office (2020b)

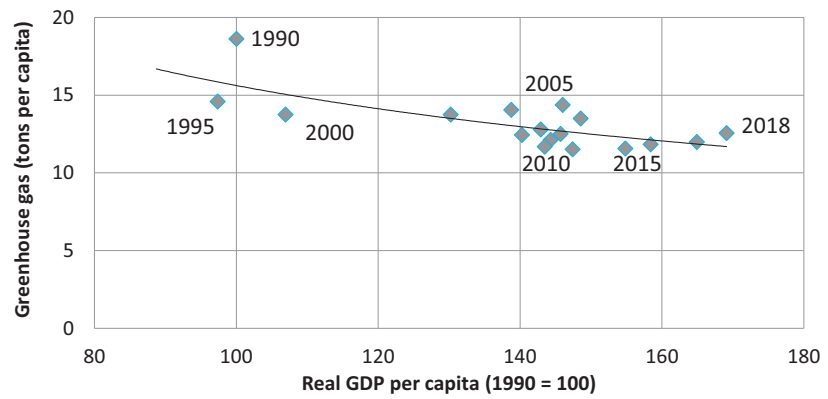

Fig. 6. Total greenhouse gas emissions and real GDP per capita in the Czech Republic.

Source: Czech Statistical Office (2020b)

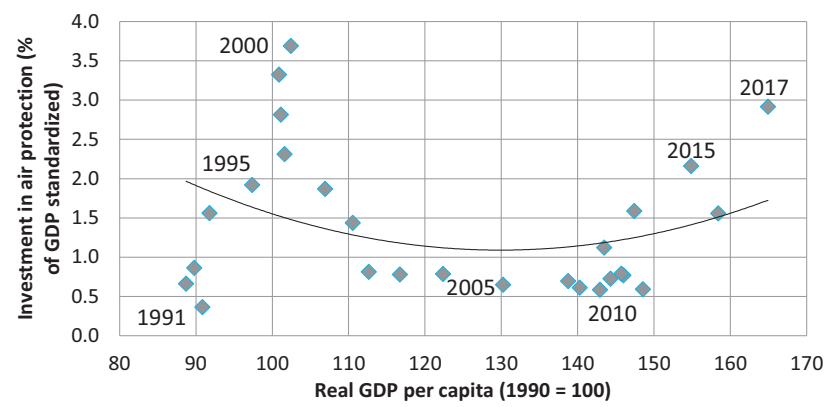

Fig. 7. Investment in air protection and real GDP per capita.

Source: Czech Statistical Office (2020b) 
in investment into air protection since 2000 , in line with the enrichment of society. So, excluding high ecological remediation as a historical outlier, the hypothesis of the environmental Kuznets curve has been confirmed.

The following conclusions can be drawn. ${ }^{9}$ If economic welfare declines, there would be a significant risk of undermining people's will to invest into protecting the environment. The decline in economic welfare, or at least deceleration in growth, might be caused by poorly set economic policies to mitigate climate change.

In connection with the setting of economic policy measures to mitigate global climate change, it is necessary to identify the costs of combating global warming and consider these in the context of efficient resource allocation to avoid negatively impacting economic welfare. Lomborg (2006) reflects on the fact that, although it currently seems important to combat global warming, economic analyses show that the costs of reducing greenhouse gases outweigh the costs of adapting to global climate change. Loužek, 2007 argues similarly when he finds that not all the costs of the fight against global warming are reasonable and that resources are often wasted.

Last but not least, when deciding on the amount of investment for environmental protection, it is also important to consider the costs of improving the degraded environment. It should be compared to the so-called preventive costs that need to be incurred to prevent environmental degradation and compensation costs on dealing with the consequences of damages (Hájek 1993).

\section{CONCLUSION}

There have been various approaches to solve environmental issues. In most cases, we encounter pronounced opinions between two extreme positions on tackling climate change. One group prefers market regulation; a second one gives priority to the functioning of an unregulated free market system. The main difference between environmentalists and their opponents is the approach to economic growth. Environmentalists generally reject uncontrolled (bustling) growth and set the aim of sustainable growth, while anti-environmentalists support economic development because they see it as an instrument to promote better protection of the environment. In national economic policies, however, the environmentalist' approaches to solving climate change predominate.

The aim of the article was to evaluate the undesirable consequences of economic policy focusing on fighting climate change in the long and short term. The paper has shown that emission regulations obstruct the affected sectors in the short term, which subsequently spills over into other sectors and brings an economic downturn.

Based on I-O table analysis, it was found that implementation of emission limits would lead, through a decline in final demand for motor vehicles, to a drop of total production from 1.61 to $5.55 \%$ and a shrinkage of GDP from 1.60 to $4.95 \%$, depending on the pricing policy of car manufacturers in the EU and the rest of the world. The calculation provides a one-time annual impact on the total production and GDP of the Czech economy. In the medium term,

\footnotetext{
${ }^{9}$ Due to the low number of observations in the short time horizon, only a qualitative analysis is possible. It is not methodologically correct to present the regression results because of the low number of observations.
} 
adjustment of the exchange rate or a more expansionary monetary policy of the Central banks might help economic growth to regain momentum.

The evaluation of long term impacts of economic policies against climate change requires knowledge of the relationship between economic development and environmental quality. The Kuznets curve proves a relatively well charted empirical relationship between the quality of the environment and the living standards, which was verified on data of the Czech Republic in this study. Poor people have a higher preference for consumption ahead of nature protection. As the society is getting richer, investments into environmental protection increase as does its quality. Only a society with enough resources and capital for research and development of new technologies can dramatically influence the quality of the environment. One major, usually neglected, implication for long-term economic policies against global warming is as follows: if policies targeted to prevent climate change slow down economic growth, less investment will be allocated to environmental protection. Reducing $\mathrm{CO}_{2}$ emissions as well as emissions of toxic solid particles or better waste management would no longer be a priority.

In the spirit of the Kuznets curve, adaptation to climate change will also be easier in wealthy economies. The fundamental question is whether the fight against climate change is more expensive than adapting to it. No one can provide absolutely certain answers, although contemporary environmentalist science pretends to do so. Its conclusions are, however, based on models with dozens of assumptions, inaccurate in forecasting even a few years ahead. It is highly risky to rely on models with 200-year forecasting horizons in today's economic decision making. Therefore, it might not be desirable for economic policy to promote measures to mitigate climate change (e.g. emission limits), because at the same time they may have negative impacts on the economy and living standards. Adaptation to climate change, on the other hand, is a continuing process; for each investment we have more information about what is needed and desirable (e.g. water retention in the landscape, construction of reservoirs etc.). Today, however, uncertain future results are perceived with the same weight as current information, which is a fundamental economic mistake.

Environmental regulation is a very complex system and emission fees are one part of the whole process. Evaluation of subsidies and estimation of their impacts on domestic production and exports is a potential topic for further extension of the research of mobility transition.

The main ambition of the paper was not to come up with a comprehensive cost-benefit analysis of distinctive environmental measures aimed at mitigating global climate change. The paper merely reveals possible unintended effects deteriorating economic activity in the short and long term, which might be taken into account by the professional community, policy makers and media. The present value of future damages of inaction must be very carefully compared with the substantial costs of contemporary and near future huge scale environmental measures. The broadly applied precautionary principle in environmental policy and a too strong emphasis on the prevention of climate change could excessively decrease future well-being. In other words, the internal rate of return of measures could be negative, which, as a result, could lead to environmental degradation.

\section{ACKNOWLEDGEMENT}

This work was supported by the intuitional support of VSE no. IP 100040. 


\section{REFERENCES}

Anderson, T. - Leal, D. (2001): Free Market Environmentalism. New York: Palgrave.

Anderson, P. L. - McLellan, R. - Overton, J. P. - Wolfram, G. (1997): Price Elasticity of Demand. MacKinac Center for Public Policy S1997-04.

Copeland, A. (2009): The Dynamics of Automobile Expenditures. Federal Reserve Bank of New York Staff Report No. 394.

Czech Statistical Office (2020a): International Trade in Goods (change of ownership). CZSO. https://www. czso.cz/csu/czso/external_trade_in_goods_according_to_the_change_of_ownership_-national_ concept-_, accessed 03/12/2020.

Czech Statistical Office (2020b): Statistical Yearbook of the Czech Republic - 2020. CZSO. https://www. czso.cz/csu/czso/3-zivotni-prostredi-hgr9vbljeu, accessed 07/12/2020.

Darwin, R. - Kennedy, D. (2000): Economic Effects of $\mathrm{CO}_{2}$ Fertilization of Crops: Transforming Changes in Yield into Changes in Supply. Environmental Modelling \& Assessment 5: 157-168.

Deryng, D. et al. (2016): Regional Disparities in the Beneficial Effects of Rising $\mathrm{CO}_{2}$ Concentrations on Crop Water Productivity. Nature Climate Change 6: 786-790.

Ehrlich, P. (1968): The Population Bomb. New York: Ballantine Books.

European Commission (2019): United in Delivering the Energy Union and Climate Action - Setting the Foundations for a Successful Clean Energy Transition. COM(2019) 285 final. Brussels: European Commission.

European Commission (2020a): Europe's Moment: Repair and Prepare for the Next Generation. https://ec. europa.eu/commission/presscorner/detail/en/ip_20_940, accessed 03/12/2020.

European Commission (2020b): Impact Assessment on Stepping up Europe's 2030 Climate Ambition. Investing in a Climate-neutral Future for the Benefit of our People. Commission Staff Working Document SWD/2020/176.

Gore, A. (2006): An Inconvenient Truth: The Planetary Emergency of Global Warming and What We Can Do About It. Pennsylvania: Rodale Press.

Greenwalt, D. (2016): The Promise of Nuclear Anxieties in Earth Day 1970 and the Problem of Quick-Fix Solutions. Southern Communication Journal 81(5): 330-345.

Grossman, G. M. - Krueger, A. B. (1995): Economic Growth and the Environment. The Quarterly Journal of Economics 110(2): 353-377.

Hájek, M. (1993): Environmental Protection Outlays. Czech Journal of Economics and Finance (Finance a úvèr) 43(10): 468-474.

Hope, C. (2006): The Marginal Impact of $\mathrm{CO}_{2}$ from PAGE2002: An Integrated Assessment Model Incorporating the IPCC's Five Reasons for Concern. Integrated Assessment Journal 6(1): 19-56.

Isard, W. - Langford, T. (1971): Regional Input-Output Study: Recollections, Reflections, and Diverse Notes on the Philadelphia Experience. Cambridge, MA: MIT Press.

ICCT (2016): 2020-2030 CO 2 Standards for New Cars and Light-commercial Vehicles in the European Union. The International Council on Clean Transportation. https://theicct.org/sites/default/files/ publications/ICCT_EU-CO2-stds_2020-30_brief_nov2016.pdf, accessed 30/11/2020.

ICCT (2019): European Vehicle Market Statistics: Pocketbook 2019/20. The International Council on Clean Transportation. https://theicct.org/sites/default/files/publications/European_vehicle_market_statistics_ 20192020_20191216.pdf, accessed 30/11/2020. 
IEA (2017): Policy Pathways Brief - Improving the Fuel Economy of Road Vehicles. https://www.iea. org/reports/policy-pathways-brief-improving-the-fuel-economy-of-road-vehicles, accessed 10/12/ 2020.

International Monetary Fund (2019): World Economic Outlook: Global Manufacturing Downturn, Rising Trade Barriers. Washington, DC.

IPCC (2018): Special Report on Global Warming of $1.5^{\circ} \mathrm{C}$. https://www.ipcc.ch/site/assets/uploads/sites/2/ 2019/06/SR15_Full_Report_High_Res.pdf, accessed 10/12/2020.

Janský, P. (2014): Consumer Demand System Estimation and Value Added Tax Reforms in the Czech Republic. Czech Journal of Economics and Finance (Finance a úvěr) 64(3): 246-273.

JATO Dynamics (2020): New Car $\mathrm{CO}_{2}$ Emissions Hit the Highest Average in Europe since 2014. JATO Dynamics. https://www.jato.com/new-car-co2-emissions-hit-the-highest-average-in-europe-since2014/, accessed 03/12/2020.

Kuznets, S. (1955): Economic Growth and Income Inequality. The American Economic Review 45(1): 1-28. Leary, N. - Adejuwon, J. - Barros, V. - Burton, I. - Kulkarni, J. - Lasco, R. (2008): Climate Change and Adaptation (Earthscan Climate). London: Routledge.

Lomborg, B. (2001): The Skeptical Environmentalist: Measuring the Real State of the World. Cambridge, UK: Cambridge University Press.

Loužek, M. (2007): Hysterie globálního oteplování [The Hysteria of Global Warming]. Centrum pro ekonomiku a politiku. http://cepin.cz/cze/clanek.php?ID=745, accessed 03/12/2020.

Meadows D. H. - Meadows, D. L. - Randers, J. - Behrens , III., W. W. (1972): The Limits to Growth. New York: Universe Books.

Mendelsohn, R. (2009): The Impact of Climate Change on Agriculture in Developing Countries. Journal of Natural Resources Policy Research 1(1): 5-19.

Miller, R. E. - Blair, D. P. (2009): Input-Output Analysis: Foundations and Extensions. New York: Cambridge University Press.

Moraga-Gonzalez, J. L. - Sándor, Z. - Wildenbeest, M. R. (2015): Consumer Search and Prices in the Automobile Market. IESE Business School Working Paper No. 1123-E.

NewsABC (2020): Euro 7 emissions standard: Is there a threat of the end of combustion engines from 2025? NewsABC.net. https://newsabc.net/euro-7-emissions-standard-is-there-a-threat-of-the-end-ofcombustion-engines-from-2025/, accessed 03/12/2020.

Nordhaus, W. (2007): A Review of the Stern Review on the Economics of Climate Change. Journal of Economic Literature 45(3): 686-702.

Nordhaus, W. - Moffat, A. (2017): A Survey of Global Impacts of Climate Change: Replication, survey methods, and statistical analysis. National Bureau of Economic Research Working Paper 2096.

OECD (2018): OECD Inter-Country Input-Output (ICIO) Tables. Organisation for Economic Co-operation and Development. http://www.oecd.org/sti/ind/inter-country-input-output-tables.htm, accessed 30/11/ 2020.

Randall, C. (2020): EU to Tighten Euro 7 Emissions Standard for all Tests. Electrive.com. https://www. electrive.com/2020/11/16/vda-worried-about-the-euro-7-emissions-standard/, accessed 03/12/2020.

Regulation (EU) 2019/631 of the European Parliament and of the Council of 17 April 2019 Setting CO2 Emission Performance Standards for New Passenger Cars and for New Light Commercial Vehicles, and Repealing Regulations (EC) No 443/2009 and (EU) No 510/2011. Official Journal of the European Union L 111/13, p. 41. https://eur-lex.europa.eu/legal-content/EN/ALL/?uri=CELEX\%3A32019R0631, accessed 30/11/2020.

Rehdanz, K. - Maddison D. (2005): Climate and Happiness. Ecological Economics 5(1): 111-125. 
Statista (2019): Average Price (including tax) of Passenger Cars in the EU in 2014 and 2018. https://www. statista.com/statistics/425095/eu-car-sales-average-prices-in-by-country/, accessed 03/12/2020.

Stern, N. (2006): Stern Review: The Economics of Climate Change. Cambridge: Cambridge University Press.

Tol, R. S. J. (2014): Correction and Update: The Economic Effects of Climate Change. Journal of Economic Perspectives 28(2): 221-226.

Train, K. E. - Winston, C. (2007): Vehicle Choice Behaviour and the Declining Market Share of U.S. Automakers. International Economic Review 48(4): 1469-1496. https:/eml.berkeley.edu/ train/ trainwinston.pdf, accessed 25/11/2020.

Transport Research Centre (2020): V roce 2019 se o čtvrtinu zvýšil počet osobních vozidel s externím nabíjením [In 2019, the number of externally charged passenger cars increased by a quarter]. https:// www.cdv.cz/tisk/v-roce-2019-se-o-ctvrtinu-zvysil-pocet-osobnich-vozidel-s-externim-nabijenim/, accessed 03/12/2020.

United Nations (2015): Paris Agreement. https://unfccc.int/files/essential_background/convention/ application/pdf/english_paris_agreement.pdf, accessed 30/11/2020, accessed 10/12/2020.

Vance, C. - Mehlin, M. (2009): Tax Policy and CO2 Emissions - An Econometric Analysis of the German Automobile Market. Ruhr Economic Papers No. 89.

Open Access. This is an open-access article distributed under the terms of the Creative Commons Attribution-NonCommercial 4.0 International License (https://creativecommons.org/licenses/by-nc/4.0/), which permits unrestricted use, distribution, and reproduction in any medium for non-commercial purposes, provided the original author and source are credited, a link to the CC License is provided, and changes - if any - are indicated. 